Old Dominion University ODU Digital Commons

Summer 2001

\title{
Isoetes Mattaponica (Isoetaceae), a New Diploid Quillwort from Freshwater Tidal Marshes of Virginia
}

Lytton John Musselman

Old Dominion University, lmusselm@odu.edu

W. Carl Taylor

Rebecca D. Bray

Old Dominion University

Follow this and additional works at: https://digitalcommons.odu.edu/biology_fac_pubs

Part of the Botany Commons, and the Plant Biology Commons

\section{Repository Citation}

Musselman, Lytton John; Taylor, W. Carl; and Bray, Rebecca D., "Isoetes Mattaponica (Isoetaceae), a New Diploid Quillwort from Freshwater Tidal Marshes of Virginia" (2001). Biological Sciences Faculty Publications. 190.

https://digitalcommons.odu.edu/biology_fac_pubs/190

\section{Original Publication Citation}

Musselman, L. J., Taylor, W. C., \& Bray, B. D. (2001). Isoetes mattaponica (Isoetaceae), a new diploid quillwort from freshwater tidal marshes of Virginia. Novon, 11(2), 200-204. doi:10.2307/3393059 


\title{
Isoetes mattaponica (Isoetaceae), a New Diploid Quillwort from Freshwater Tidal Marshes of Virginia
}

\author{
Lytton John Musselman \\ Department of Biological Seiences, $302 \mathrm{~F}$ Mills Godwin Building/45 \\ University, Norfolk, Virginia 23529-0266, U.S.A. Imusselnı@odu.edu
}

\section{W. Carl Taylor}

Department of Botany, Milwaukee Public Museum, 800 West Wells Street, Milwattkee, Wisconsin 53233-1478, U.S.A.ct@mpm.edu

\section{Rebecca D. Bray}

Department of Biological Sciences, Old Dominion University, Norfolk, Virginia 23529-0266, U.S.A.rbray@odu.edu

ABsTRACT. Isoetes mattaponica is a rare quillwort of freshwater tidal rivers of eastern Virginia with a somatic chromosone number of $2 n=22$. Megaspores have low rugulate muri on both the proxinial and distal surfaces; the girdle is broad. Microspores are echinate-spinose with ornanented spines. Isoetes mallaponica may be one of the parents of sevcral polyploids in the Southeastern United States.

Key words: Isoetacede, Isoetes, North Anmerica, quillwort. United States. Virginia.

Chesapeake Bay quillworts have been extensively studied (reviewerl in Musselman \& Knepper, 1997, and Caplen \& Werth, 2000a) but largely extirpated due to pollution and urbanization. The following taxa are known fron the sonthern parts of the Chesapeake Bay (Musselman \& Knepper, 1997): Isoetes engelmannii A. Braun $(2 n=22)$ : $I$. saccharata Engelmann $[2 n=44$, ineluding $/$. hyemalis Brunton $(2 n=44)]$ : and $l$. acadiensis Kott $(2 n=44)$. For a clear understanding of relationships among these polyploids, knowledge of the basie diploids is essential. A new diploid species from the freshwater tirlal marshes of Virginia is describerl.

Isoetes mattaponica L. J. Musselman \& W. C. Taylor, sp. nov. TYPE: U.S.A. Virginia: King Willian Comty, Mattaponi River, plants in Pontederia cordata-Nuphar luteum marsh, along a tital shore of the Mattaponi River, ca. $0.75 \mathrm{~km} \mathrm{~S}$ of Aylett. 7 Aug. 1997. W. C. Tavlor 60.52 (hololype. MII). Figures $1-6$.

Planta acuatica, emergens, amphibia aestus zonam ladbitans; caudice subgholoso, bilobo. Folia sivide viriclia, basin versus pallida, in spiram disposita, usque ad cia. 25 $\mathrm{cm}$ fonga, (al. I Inm lata ad medium longitudinis, flexibilia. Sporangium lasate, obovatum ad late ellipticum, ca. 2.5-3.5 mm longum: paricte fascieutis sparsis linearibus at oblongis collutarum brunnearum unius ad quattuor maculato, velo incompleto membranaceo pro parte 25-75\% tecto: megasporis albis, 280-360 $\mu \mathrm{m}$ diametro $(x=330$ $\mu \mathrm{m})$, inconspicue verrucato-rugatis, cingulo lato; microsporate pallicle canis in massa, $22-28 \mu \mathrm{m}(x=25 \mu \mathrm{m})$, echinatis. Chromosomatum numerus $2 n=22$.

Plant ayuatic, emergent, ticlad-amplibian. Rootstock subglobose, bilobed. Leaves bright green, pale toward base, spirally arranged. ('a. 25 cm long, ca. I mm wide at mid length, pliant. Labium absent. No peripheral strands present. Central intrastelar canal one. Velum incomplete, membranous, covering $\pm 25-75 \%$ of sporangium wall. Sporangia basal, obovate to widely elliptic, ea. 2.5-3.5 $\mathrm{mm}$ long, walls spotted with scattered, linear to oblong clusters of 1 to 4 brown-colored cells. Megaspores white, (a. 280-360 $\mu \mathrm{m}$ diam. $(x=330 \mu \mathrm{m})$, obscurely verrucale-rugate, girdle wide, ormamentation obscure. Microspores light gray in mass. ca. 22-28 $\mu \mathrm{m}$ long $(x=25 \mu \mathrm{m})$, echinate. Chromosomes: $2 n=22$.

Distribution. Chickalıominy, Pamunkey, ant Mattaponi Rivers of eastern Virginia.

Mattaponi is the name of a tribe of Native Americans living along these coastal rivers.

Paratypes. U.S.A. Virginia: King William County, Aylett, Taylor 601.52 (MII), Musselman 98902 (0DU), Musselman 99176 (ODU): King and Queen Connty, $1.5 \mathrm{~km} \mathrm{~S}$ of Aylett. Musselman 99178 (()DU): New Kent County, 3.0 km N of Panunkey Indian Reservation, Musselman 96042 (()DU): Clarles City County, $4.5 \mathrm{~km} \mathrm{~S}$ of Walker Dam. $M$. Pease s.n. (ODU): Wilcox Ner'k. Musselman 99186 (mixed collection) (OD)( ). 


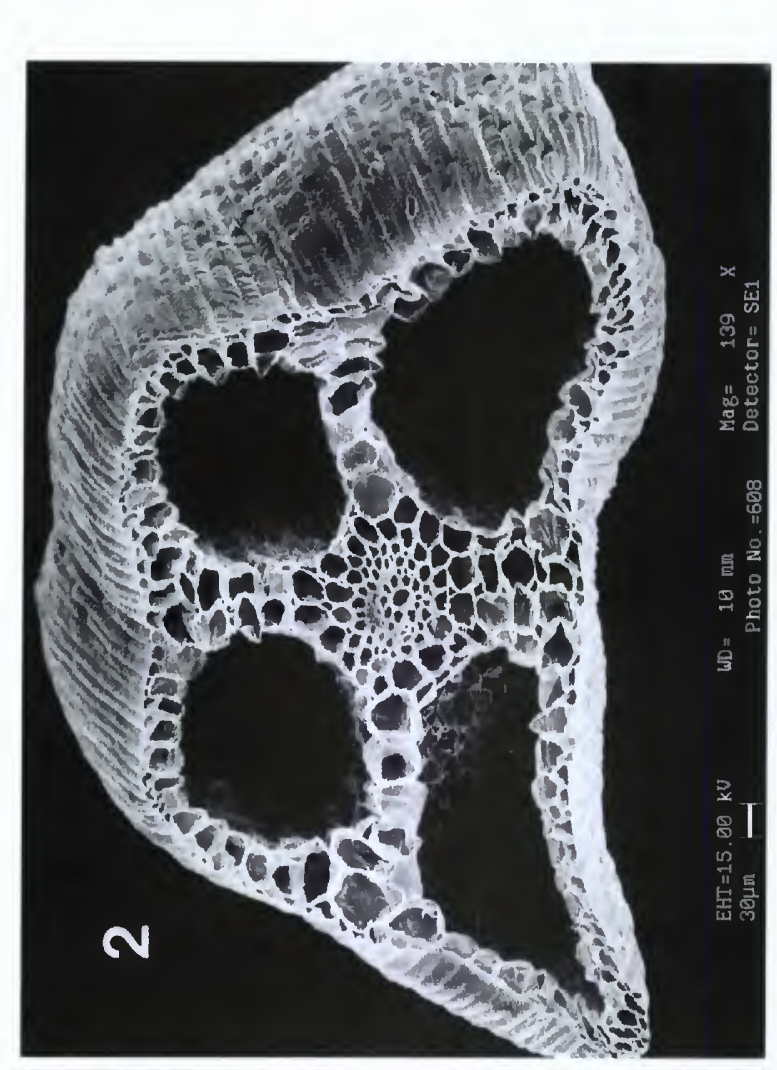

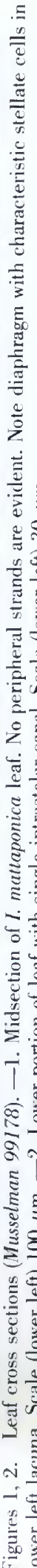

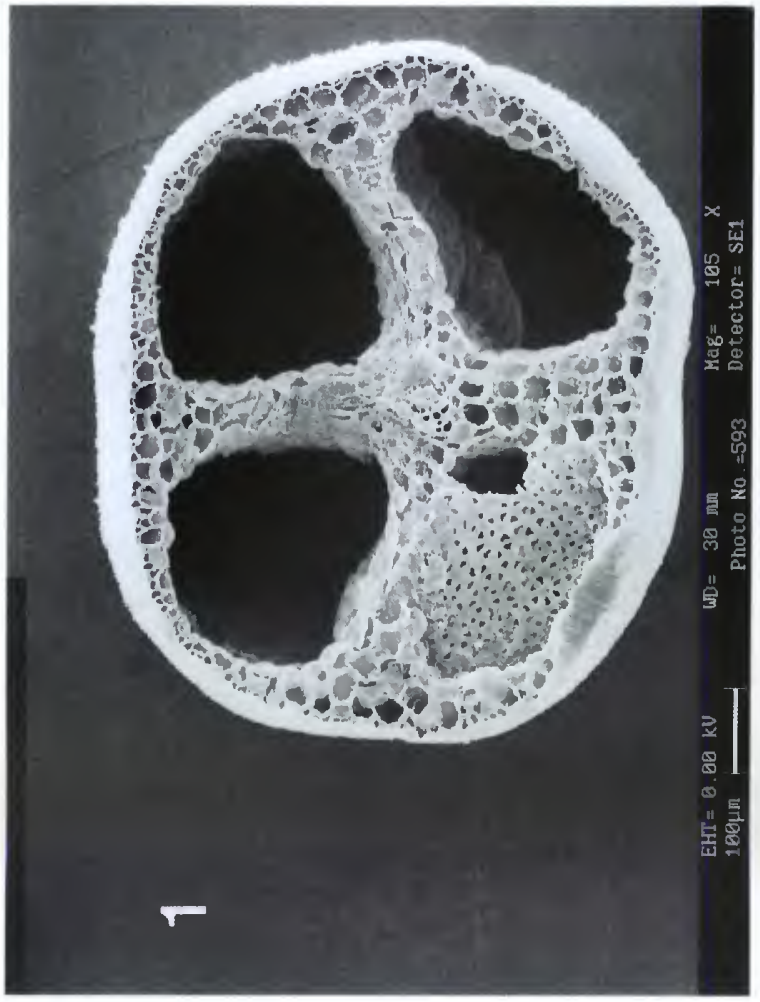




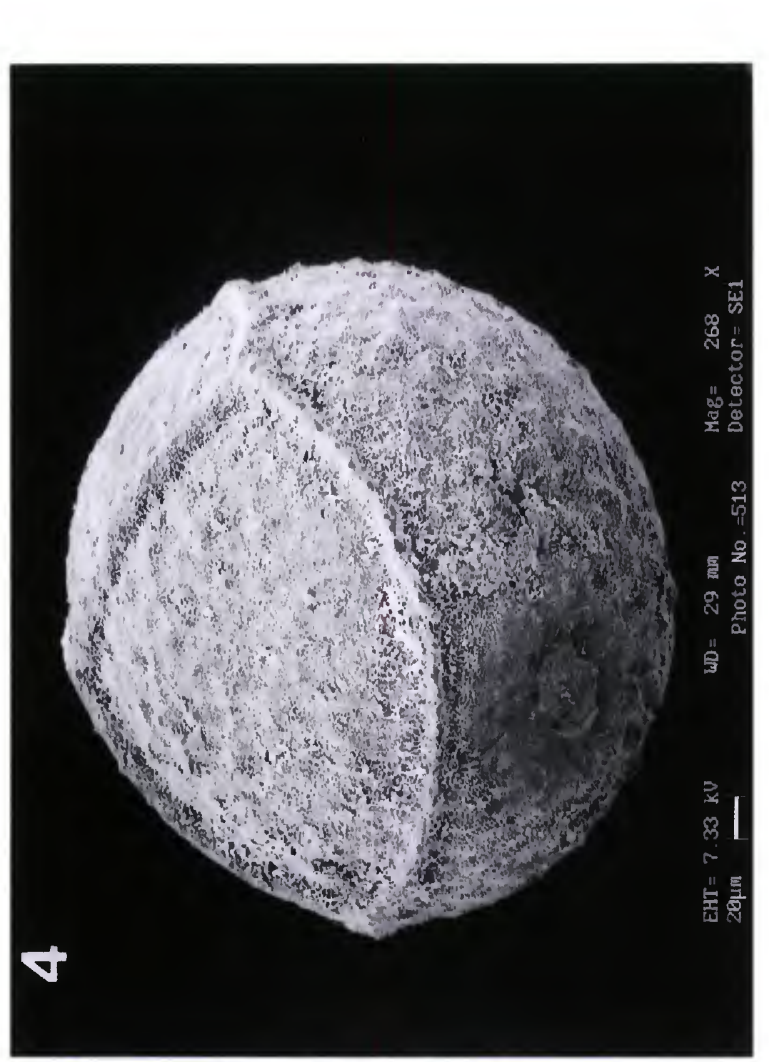

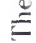

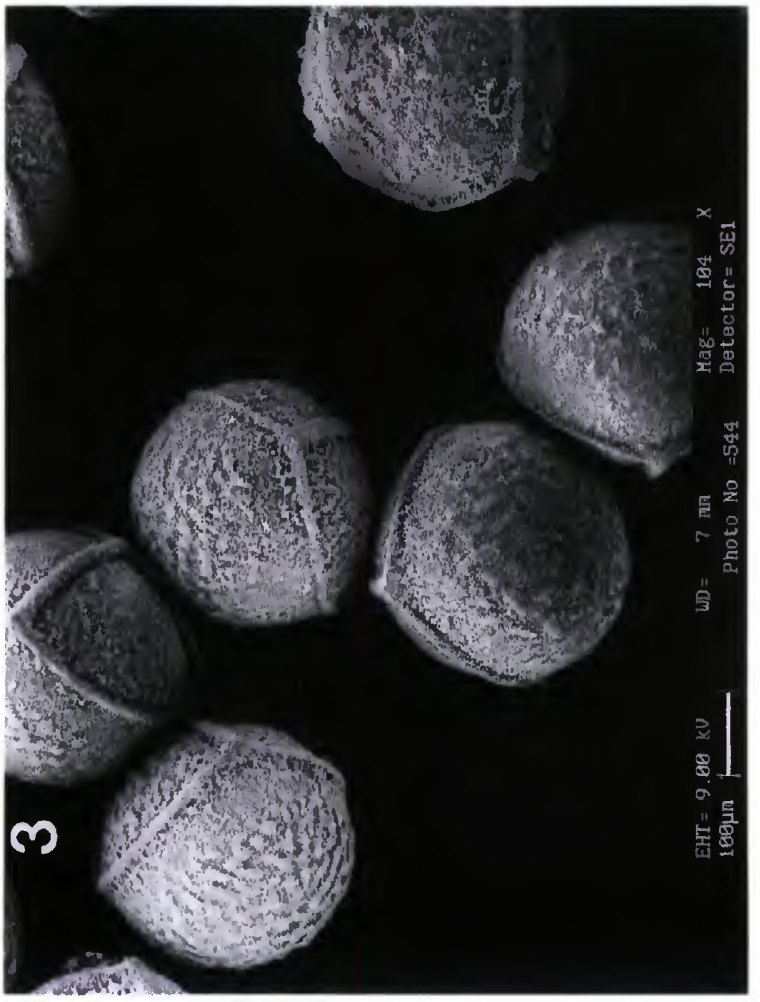




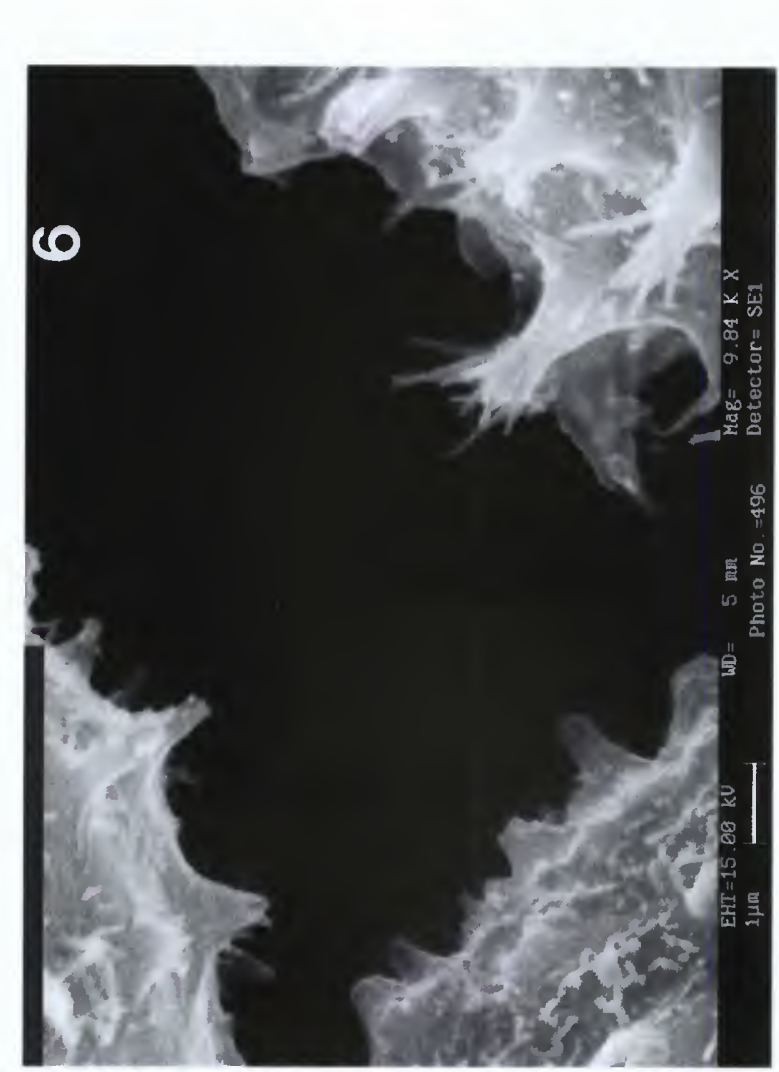

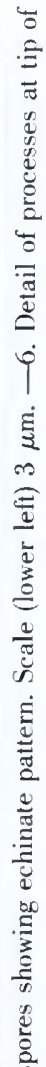

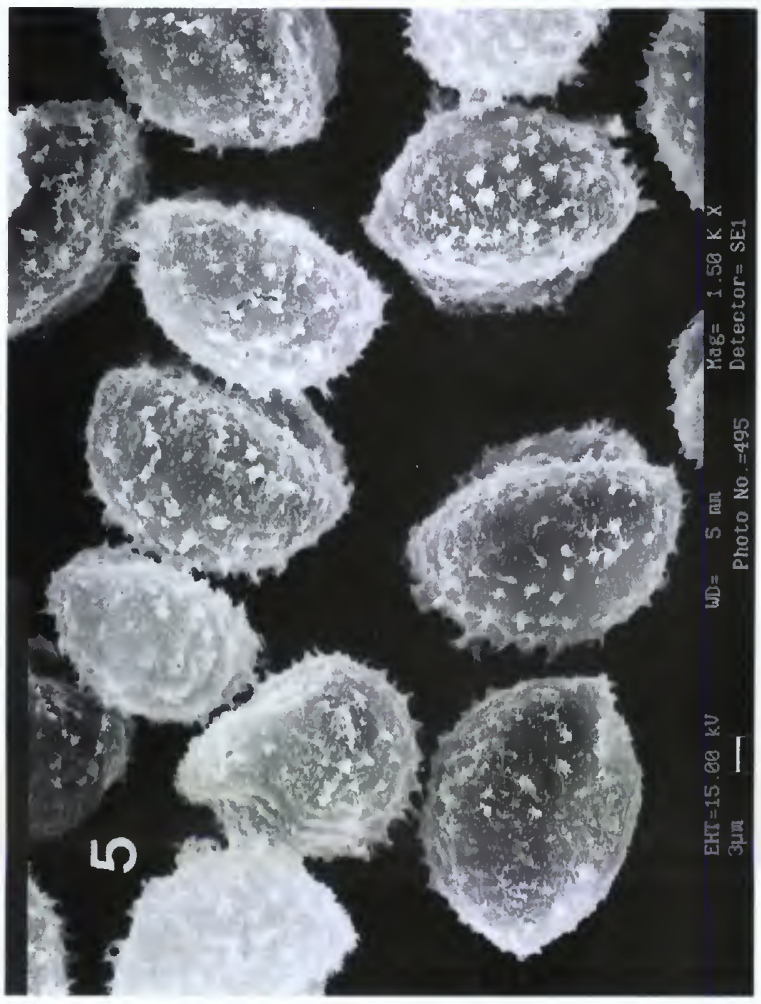


leaffeatures. The leaves of Isoetes mattaponica lack peripleral strands and have a single intrastelar canal (Figs. I. 2). Isoetes engelmanuii, I. acadiensis, and $I$. hyemalis also possess a single inIrastelar canal (Bray, unpublished). More populations and taxa need to be examined to establish the taxomomic value of peripheral strands. Stomata are present on the leaves of I. manaponica. Unlike most soutleastern quillworts (Bray \& Musselman, umpulishled), I. mattaponica lacks scales.

Spore unorphology and size. Isoetes acadiensis also grows in the tidal rivers of southeastern Virginia and superficially resembles I. matlaponica. Megaspore size and ormanentation differ between the two taxal, lowever. Spores of I. matlaponica are slightly smaller $(x=330 \mu \mathrm{m})$ than I. acadiensis $(x$ $=412 \mu \mathrm{m}$ ). Isoetes mallaponica megaspores (Figst. 3, 4) have an obscure. low. rugulate sculpturing: those of 1 . acadiensis are boldly rugulate-reticulate. Lastly, the girdle of I. matraponica is wider and less ormamented than that of $I$. acadiensis.

Megaspores of $I$. mallaponica superficially resemble those of the basit diploid I. melanopoda Gay \& Durien. However, the rugulate, low $(<5$ $\mu \mathrm{m})$, rounded muri of $I$. mallaponica megaspores differ from the tuberculate ornamentation of $I$. melanopoda (Taylor et al., 199:3). They more rlosely resemble the muri of $I$. acadiensis, a tetraploid that grows with $I$. mallaponica.

Mierospores of I. mallaponica are strongly echinate (Fig. 5) and have fringed processes at the tips of some spines (Fig. 6). Fringed processes oceur on several North American speries of Isoetes (Mussolman, unpublished).

Megaspores mature from the miclalle of Jume to the midclle of Augnst. Microspores develop from the first of July to the end of August. By October, nost sporophylls have decayed and only a few depauperate leaves, lacking sporangia. remain. Like oller Chesapeake Bay submergent quillworts, I. mallaponied stays green during the winter.

Cylology. Isoetes mathaponica has a basic diploid chromosome number of 22 . Only two diploid quillworts have heen described from North Ameriea the past one hundred years-I. legetiformaus Rury and 1. prototypus D. M. Britton (Taylor et al.. 1993). Like I. mallaponica, these two diploids also hase at very restricted range (Taylor et al.. 19933).

Field characters. In conmon with most quillworts, there is little to distinguish /. maltaponica from other speries. Its general appearance and chromosome number have similarities to I. melanopola $(2 n=22)$, a widle-ranging, varialble species of North America with shallowly ornamented megaspores (Taylor et al., 1993).

Molecular characlers. Recently. Saralı Hoot (pers. comm.) has used the second intron of the leafy (Ify) in her phylogentetic studies of Isoestes. Her preliminary sequence data support I. matlaponica as a rlistinct species with about 15 unique substitutions and one indel not found in any other species of Isoetes.

In an allozyme study of the $I$. riparia eomplexall tetraploids $(2 n=44)$ - Caplen and Werth $(200(0)$ ) found $/$. mallaponica to be one of the most likely parents for ten different populations of " $\%$ riparia" in the Southeast.

Ecology. The rivers in which this quillworl grows are unique freshwater tidal river systems of Chesapeake Bay. At their borders lie extensive and relatively undisturbed marshes. Federally endangrered plants found here include Aeschynomone virginica (I.) Britton, Sterns \& Poggenburg and /leulianthus (= Micranthemum) micranthemoides Nottall. Isoetes mallaponica is part of a guilal of isoetid plants (plants with rosette leaves, tufted roots, and often CAM plotosynthesis). Isoetids in these marshes include Eriocanton partieri Robinson, Lilaeopsis chinensis (L.) Kuntze, and Sagitharia subulata (l.) Buchenan. Other species that grow with I. maltaponica are Acorus calamuss L., Elatine triandra Schkulır. Eleocharis parvula (Roemer \& S(hultes) Link. Nuphar advena (Aiton) Aiton f., Orontium aqualicum I... Pellandra virginica (L.) Schott \& Endlicher, Pontederia cordana L... ant $Z_{i-}$ zania aquatica $\mathrm{L}$.

Isoeles matlaponica, like some of its (cohorts. al)parently is a rare plant. We lave seen it at only five sites in four Virginia rounties: Charles City, King and Queen, King William, and New Kent. No previous collections are known. Careful searehes should be made, however, before populations are adversely affected by marsh disturhance through water withdrawal and urbanization.

Actinowledgutents. We have benefited from discussions witl C. Caplen, R. J. Hickey. K. Heafner. and D). Knepper. Doug Oavis, I)avis Envirommental, leelped locate populations. Plates were made loy R. Jones. Michatel Aclam prepared the materials for electron microscopy. Researcle was supported. in part, ly the Mary Payne Hogan Fund.

\section{Literalure Cited}

Capplen, C. A. \& C. R. Werth. 200()a. lsozymes of the Isoctes riparia complex, I. Crenetic varialion and relatedluess of diploid species. Sysi. Bol. 25: 235-259.

$\&-.2000)$. Isozymes of the Isoetes riparia conplex, 11. Ancestry and relationships of polyploids. Syst. Bol. 25: 260-280.

Mussclman, L. J. \& D. A. Kinepper. 1997. Chesapeake Bay quillworts. Wetland J. 9: 3-6.

Taylor, W. C.. N. 'T. Luelke, D. M. Britton, R. J. Hickes \& D. F. Brunton. 1993. Isoetaceae H. C. I. Reichentbach-()uillwort Fantily. Pp. 6.1-75 in Flora of North Ameriea Editorial Committere (editors), l'lora of Nortl America North of Mexico, Vol. 2. Oxford Univ. Presis, Now York. 